\title{
Continent cutaneous diversion pouch calculi
}

\author{
Samarth Agarwal, ${ }^{1}$ Deepanshu Sharma, ${ }^{2}$ Akansha Gupta, ${ }^{3}$ Satyanarayan Sankhwar ${ }^{4}$
}

'Department of Urology, King George's Medical University, Lucknow, Uttar Pradesh, India ${ }^{2}$ King George's Medical University, Lucknow, Uttar Pradesh, India

${ }^{3}$ Department of Obstetrics and Gynaecology, Jolly Grant Medical College, New Delhi, India

${ }^{4}$ Department of Urology, CSM Medical University (Upgraded KGMC), Lucknow, Uttar Pradesh, India

\section{Correspondence to} Dr Samarth Agarwal, rebellite@gmail.com

Accepted 29 August 2018

\section{DESCRIPTION}

A 62-year-old female patient who presented at our centre with dull aching right flank pain of 6 months duration. She had a history of radical cystectomy and cutaneous continent urinary diversion (Indiana pouch) done 20 years ago for muscle invasive urothelial carcinoma of urinary bladder. The patient followed up regularly since operation. However, for last 3 years, the patient was lost to follow-up. On further eliciting the history, she mentioned her inability to perform pouch irrigation and clean intermittent catheterisation regularly during this period.

On examination, a lump was palpable in the right lumbar region in the region of continent pouch. It was firm in consistency around $5 \times 5 \mathrm{~cm}$ in size and did not move with respiration. There was no pain/ tenderness on palpation. The stoma was healthy, flush to skin, functioning and easily catheterisable.

Her complete haemogram including renal function test and liver function test were normal. A plain abdominal X-ray revealed multiple radioopaque shadows in right lumbar region (figure 1). Non-contrast CT scan confirmed these findings and showed multiple calculi in pouch with largest measuring $3 \times 4 \mathrm{~cm}$ with minimal hydroureteronephrosis in bilateral kidney.

Because of presence of multiple large calculi, it was decided to undertake open surgical approach

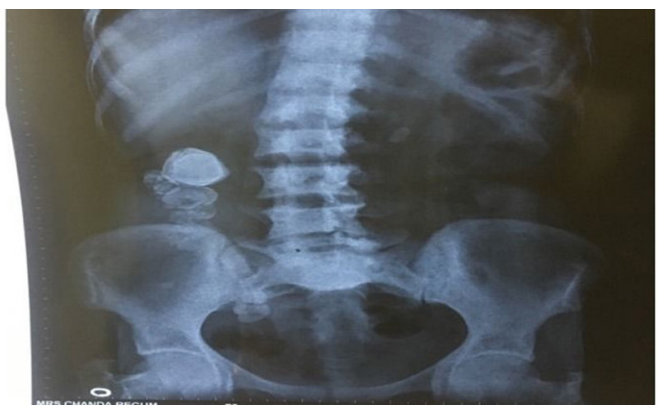

for removal of pouch calculi. The patient was kept on liquid diet a day before surgery. We did not give any mechanical bowel preparation. Intravenous metronidazole and third-generation cephalosporin were given on the day of surgery as well as in the postoperative period. A midline infraumbilical transperitoneal incision was taken, and continent pouch was carefully identified and dissected all around. With help of stay sutures, a pouchotomy of around $3 \mathrm{~cm}$ was performed at anterior surface, and multiple calculi were delivered out with help of Desjardins stone removal forceps as shown in figure 2.

The pouchotomy was then closed primarily in two layers water-tight fashion with polyglycolic sutures. A Foley catheter $14 \mathrm{Fr}$ was also placed in the stoma intraoperatively and removed after 2 weeks.

Postoperative period was uneventful. A repeat X-ray kidney-ureter- bladder did not reveal any residual calculus in the pouch.

At 6 months follow-up, the patient was doing well with no recurrence of pain and calculi.

Pouch calculi is a known phenomenon in patients with cutaneous continent pouch and has been reported in $2.9 \%$ to $12.9 \%$ of various studies. A number of factors play an important role like urea-splitting organisms predisposing to struvite stone formation intestinal mucus secretion which acts

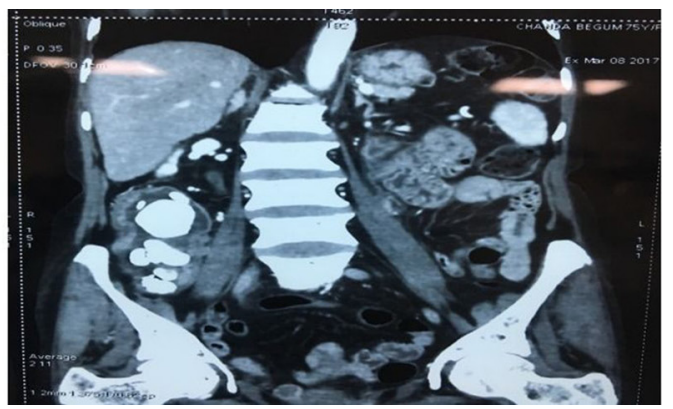

Figure 1 X-ray kidney-ureter-bladder and coronal CT section showing multiple radio-opaque shadows in the region of Indiana pouch.
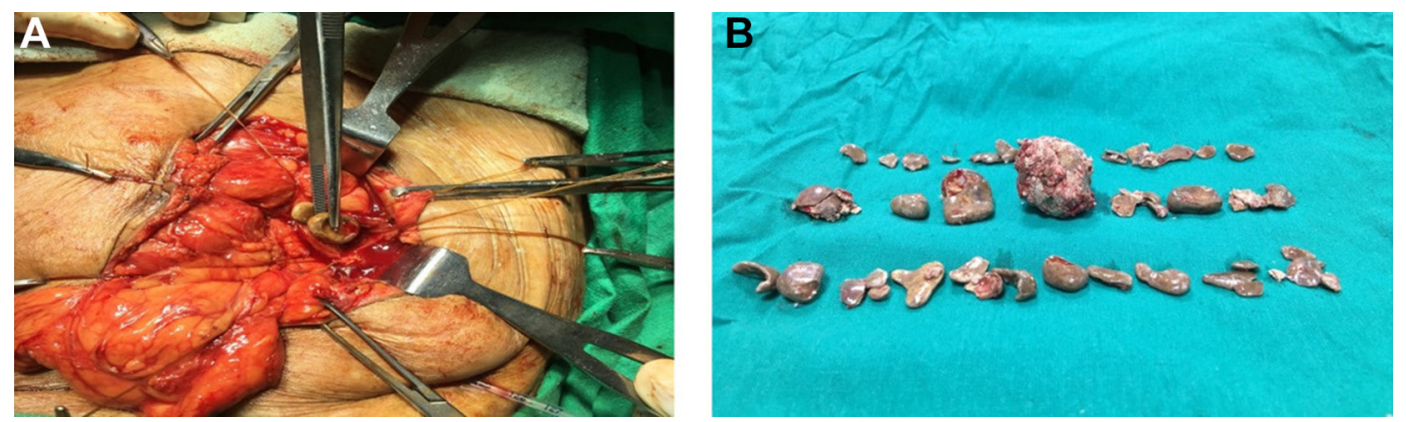

Figure 2 (A) Open surgical approach to remove the pouch calculi. (B) Surgically removed multiple pouch calculi. 


\section{Learning points}

- Pouch calculi is a late complication of continent cutaneous diversion pouch, and patient may present after many years.

- Patients need to be counselled regarding regular and lifelong follow-up.

- Pouch irrigation and drainage, in form of clean intermittent catheterisation, along with adequate fluid intake is required to prevent such a drastic complication.

- Open surgical removal of large burden pouch calculi remains a viable treatment option for such cases.

as a nidus for crystal accumulation or metabolic acidosis which promotes demineralisation and increases calcium excretion. ${ }^{1}$

Pouch calculi can be treated by a variety of approach. Traditionally, open surgical approach was preferred modality. However, endoscopic and laparoscopic approaches, Extracorporeal Shock Wave Lithotripsy (ESWL) and percutaneous removal of calculi have all been described for patients with low stone burden disease. ${ }^{23}$ Open poucholithotomy remains an excellent option for primary management of large reservoir stone burden as was also seen in our case.
Pouch irrigation and drainage in form of clean intermittent catheterisation are the necessary preventive measures along with adequate fluid intake. Patients need to be counselled regarding these steps together with need for regular follow-up. Such patients usually require lifelong follow-up.

Contributors SA: concept, design, supervision, processing, writing manuscript and critical analysis. DS: concept and design. AG: supervision and processing. SS: concept, supervision and writing manuscript.

Funding The authors have not declared a specific grant for this research from any funding agency in the public, commercial or not-for-profit sectors.

Competing interests None declared.

Patient consent Obtained.

Provenance and peer review Not commissioned; externally peer reviewed.

\section{REFERENCES}

1 Terai A, Ueda T, Kakehi Y, et al. Urinary calculi as a late complication of the Indiana continent urinary diversion: comparison with the Kock pouch procedure. J Urol 1996;155:66-8.

2 Benson MC, Olsson CA. Continent urinary diversion. Urol Clin North Am 1999:26:125-47.

3 Rowland RG, Kropp BP. Evolution of the Indiana continent urinary reservoir. J Urol 1994;152:2247-51.

Copyright 2018 BMJ Publishing Group. All rights reserved. For permission to reuse any of this content visit http://group.bmj.com/group/rights-licensing/permissions.

BMJ Case Report Fellows may re-use this article for personal use and teaching without any further permission.

Become a Fellow of BMJ Case Reports today and you can:

- Submit as many cases as you like

- Enjoy fast sympathetic peer review and rapid publication of accepted articles

- Access all the published articles

- Re-use any of the published material for personal use and teaching without further permission

For information on Institutional Fellowships contact consortiasales@bmjgroup.com

Visit casereports.bmj.com for more articles like this and to become a Fellow 